\title{
Physical Exercise on Inflammatory Markers in Type 2 Diabetes Patients: A Systematic Review of Randomized Controlled Trials
}

\author{
Luciana Costa Melo, ${ }^{1,2,3}$ Jaime Dativo-Medeiros, ${ }^{1,2,3}$ Carlos Eduardo Menezes-Silva, ${ }^{1,2,3}$ \\ Fabiano Timbó Barbosa, ${ }^{1}$ Célio Fernando de Sousa-Rodrigues, ${ }^{1}$ and Luiza A. Rabelo ${ }^{1,2,3,4}$ \\ ${ }^{1}$ Programa de Pós-Graduação em Ciências da Saúde, Instituto de Ciências Biológicas e da Saúde, Universidade Federal de Alagoas, \\ Campus A. C. Simões, Av. Lourival Melo Mota, s/n, Tabuleiro do Martins, 57072-900 Maceió, AL, Brazil \\ ${ }^{2}$ Laboratório de Reatividade Cardiovascular, Setor de Fisiologia, Núcleo de Síndrome Metabólica, \\ Instituto de Ciências Biológicas e da Saúde, Universidade Federal de Alagoas, Maceió, AL, Brazil \\ ${ }^{3}$ Instituto Nacional de Ciência e Tecnologia em Nanobiofarmacêutica (N-BIOFAR), Belo Horizonte, MG, Brazil \\ ${ }^{4}$ Max Delbrück Center for Molecular Medicine, Berlin, Germany
}

Correspondence should be addressed to Fabiano Timbó Barbosa; fabianotimbo@yahoo.com.br and Luiza A. Rabelo; luizaa.rabelo@gmail.com

Received 15 October 2016; Revised 7 December 2016; Accepted 23 February 2017; Published 19 March 2017

Academic Editor: Sara Baldelli

Copyright (C) 2017 Luciana Costa Melo et al. This is an open access article distributed under the Creative Commons Attribution License, which permits unrestricted use, distribution, and reproduction in any medium, provided the original work is properly cited.

Background. Type 2 diabetes mellitus (T2DM) is a serious disease associated with high morbidity and mortality. Scientific findings showed that physical exercise is an option for treatment of these patients. This study's objective is to investigate the effects of supervised aerobic and/or resistance physical training on inflammatory markers in subjects with T2DM. Methods. A systematic review was conducted on four databases, MEDLINE, CENTRAL, LILACS, and Scopus, and manual search from 21 to 30 November 2016. Randomized clinical trials involving individuals diagnosed with T2DM, who have undergone supervised training protocols, were selected in this study. Results. Eleven studies were included. Studies that evaluated control group versus aerobic exercise reported controversial results about the effectiveness of physical training in modifying C-reactive protein (CRP) and cytokine levels. The only variable analyzed by the six studies in comparison to the control group versus resistance exercise was CRP. This protein showed no significant difference between groups. Between the two modes of exercise (aerobic and resistance), only one study demonstrated that aerobic exercise was more effective in reducing CRP. Conclusion. The evidence was insufficient to prove that aerobic or resistance exercise improves systemic levels of inflammatory markers in patients with T2DM.

\section{Introduction}

The term diabetes mellitus (DM) describes a metabolic disorder of multiple etiologies characterized by chronic hyperglycemia, with carbohydrate, fat, and protein metabolism disorders resulting from defects in insulin secretion or action [1].

According to statistics, a DM epidemic is underway [2]. In 1985, an estimated 30 million adults around the world had diabetes; by 1995, this number had increased to 135 million, reaching 347 million in 2013, and diabetes is predicted to be the 7 th leading cause of death by the year 2030 [3]. In this scenario, type 2 diabetes (T2DM) is the form present in $90 \%$ to $95 \%$ of cases [3].
Hyperglycemia, the main signal of DM, is even one component of the metabolic syndrome (SMet) which can be defined as the coexistence of metabolic disorders (abdominal obesity, hypertriglyceridemia, low HDL cholesterol, high blood pressure, or high fasting glucose) [4]. Although the metabolic pathways linking these disturbances are not completely clear, a proinflammatory state has been found to be an important element in the pathophysiology of the syndrome or T2DM $[5,6]$.

Obesity, especially visceral, is one of the most important factors in the development of diabetes through various mechanisms, such as increased circulating free fatty acids, adiponectin decrease, and secretion of cytokines in the 
adipose tissue, such as tumor necrosis factor-alpha (TNF- $\alpha$ ) and interleukin-6. The proinflammatory molecules produced in the adipose tissue can activate pathways that result in disruption of systemic insulin sensitivity and glucose homeostasis that are characteristic of T2DM [5].

In addition to the participation of inflammatory processes in the pathogenesis of diabetes, evidence has shown that hyperglycemia itself contributes to the generation of proinflammatory factors. Hyperglycemia promotes the production of interleukin- $1 \beta$ (IL- $1 \beta$ ) by pancreatic $\beta$-cells. IL$1 \beta$ induces the production of various types of cytokines and chemokines through activation of the nuclear factor$\kappa \mathrm{B}$, which triggers the recruitment of macrophages [7]. In fact, cross-sectional and prospective studies have described elevated levels of C-reactive protein (CRP) [8], cytokines [8$10]$, and chemokines [8-10] in patients with T2DM.

With regard to diabetes treatment, physical exercise stands out as an important ally for glycemic control and other comorbid factors, such as hypertension and dyslipidemia, and for reducing cardiovascular risk [11, 12]. It is well established in the literature that physical exercise improves insulin sensitivity [13], increasing glucose uptake in muscles and adipocytes and reducing blood glucose levels [14]. Moreover, exercise increases blood glucose uptake by the muscles through insulin-independent mechanisms that involve GLUT4 activation by muscle contraction [15]. Thus, physical exercise facilitates glucose metabolism and its efficiency, improving glycemic control, which can be observed by the lower basal and postprandial insulin concentrations and the reduction of glycated hemoglobin in physically active diabetics when compared to sedentary patients [16, 17]. It is important to consider that the normalization of blood glucose is not sufficient to remove clinical outcomes in type 2 diabetes [17]. Despite the above-described scenario, to date, no reviews have demonstrated the effects of physical exercise on the inflammation characteristic of diabetes. Therefore, this study aims to investigate the effects of supervised aerobic and/or resistance physical training on inflammatory markers in T2DM patients. We ask for scientific evidence on randomized controlled trials in which patients with T2DM performed supervised exercise training protocols.

\section{Methods}

A protocol was drawn up in preparation for this review, which is available upon request to the corresponding author should there be a need for analysis. The study is reported according to the guidelines of the "Preferred Reporting Items for Systematic Reviews and Meta-Analyses" (PRISMA Statement; Supplementary Data available at https://doi.org/10.1155/2017/ 8523728) [18]. The results were not influenced by the source of the studies (authors or institutions where they were carried out). This systematic review was not registered with the International Prospective Register of Systematic Reviews (PROSPERO).

The search strategy aimed to identify randomized controlled trials (RCTs) that used physical exercise as a treatment strategy for patients with T2DM.
2.1. Databases. The studies were identified in four electronic databases: MEDLINE (via PubMed, from 2006 to November 2016), Cochrane Central Register of Controlled Trials (CENTRAL, Issues 3, 2016), Scopus (from 2006 to November 2016), and LILACS (via BIREME interface, 2006 to November 2016). The search procedure was carried out from 21 January to 26 November 2016.

The strategy used here considered the terms of most interest to the review: "Diabetes Mellitus," "Exercise" and "Randomized controlled trial." A combination of three terms were used in PubMed, Scopus, and LILACS: "Diabetes Mellitus" AND "Exercise" AND "Randomized controlled trial”, while a combination of two terms were used in CENTRAL: "Diabetes Mellitus" AND "Exercise". In addition, searches were made in the reference lists of the selected articles for inclusion in this review. Text filters, availability, and/or origin of the study were not used. We used filters to publication date (articles published in the last 10 years) and age (studies with subjects aged 18 years or older).

2.2. Selection of Studies. RCTs were selected in which the participants were 18 years old or older, who had been definitively diagnosed with T2DM. The diagnosis was considered based on information contained in the article, regardless of the criteria used, without gender restriction.

The search focused on trials that used aerobic and/or resistance exercise in programs supervised by professionals. Trials in which the exercise program was associated with dietary or prescription medications to control T2DM were excluded. This could be a source of bias because the effects on the analyzed variables could be from these associated treatments.

We considered the control group as subjects that did not do supervised exercise program, maintained their daily routine activities, or were asked to perform less than 150 minutes of low grade exercise per week. We considered placebo training when subjects performed the same kind of exercise of trained groups but without load.

Trials composed of two groups performing different kinds of exercise (aerobic and resistance) were considered to compare the most effective exercise on modifying inflammatory biomarkers. On the other hand, studies comparing two groups of the same exercise on different intensities were not considered, because there are a large variety of intensities what could be a source of bias in the analysis.

Based on this selection, three possibilities were considered for analysis between groups: (i) aerobic exercise versus control, (ii) resistance exercise versus control, and (iii) aerobic exercise versus resistance exercise.

The first variable of interest was the plasma CRP level, because it is an inflammatory marker provenly altered in patients with T2DM [7]. Plasma cytokines associated with inflammation (adiponectin, tumor necrosis factor- $\alpha$, interleukins, and/or other cytokines with specific activity) were considered secondary variables.

The articles were identified by three authors independently, based on the titles and abstracts. Disagreements about their eligibility were resolved in a consensus meeting, after which the full texts of the selected articles were downloaded. 


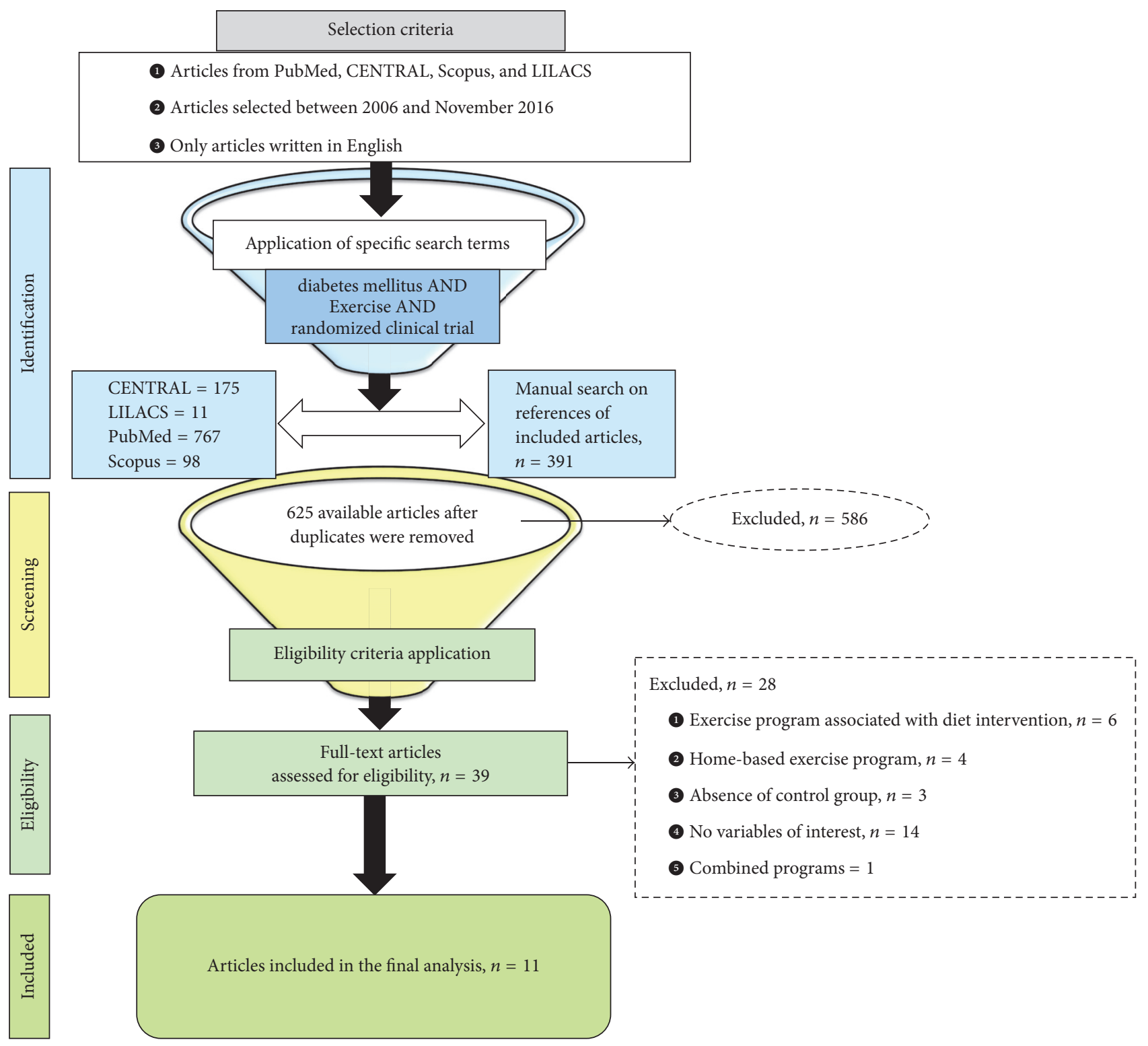

FIGURE 1: Workflow of information through the different phases of the systematic review.

The articles were then evaluated again independently by three authors of this review. The RCTs included in this review were defined by consensus. Figure 1 summarizes the search methodology.

2.3. Extraction of Data. Preformatted forms were filled out containing identifying information about the study, characteristics of the sample, and data on the variables of interest. Data not available in the article were requested by email from the authors.

The data extraction procedure was performed by three authors independently. Each author read the included article and plotted the data of interest on tables previously designed. After this, the tables were compared to confirm accuracy of the extraction. Any disagreements about how to complete the forms were resolved in a consensus meeting.
Data from included studies were described as measures of central tendency and dispersion. Analysis was performed according to possible comparisons: (i) aerobic exercise versus control, (ii) resistance exercise versus control, and (iii) aerobic exercise versus resistance exercise.

2.4. Ethical Approval. This is a literature review-based study that did not involve experiments with animals or humans. No specific ethical approval is required for this kind of study and informed consent for participation is not applicable.

\section{Results}

3.1. Selection of Studies. The studies to be included in this review were identified during the period of 21 January 2016 to 26 November 2016. The search strategy resulted in the 
TABLE 1: Treatments compared in the included studies.

Control group versus aerobic training

Kadoglou et al., 2007 [26]

Oberbach et al., 2008 [21]

Jorge et al., 2011 [22]

Swift et al., 2012 [28]

Kadoglou et al., 2012 [23]

Kadoglou et al., 2013 [29]

Moghadasi et al., 2013 [30]

Control group versus resistance training

Aerobic training versus resistance training

Brooks et al., 2007 [20]

Jorge et al., 2011 [22]

Swift et al., 2012 [28]

Kadoglou et al., 2012 [27]

Kadoglou et al., 2013 [29]

Mavros et al., 2014 [25]
Jorge et al., 2011 [22]

Sukala et al., 2012 [24]

Swift et al., 2012 [28]

Kadoglou et al., 2013 [29] identification of 1,051 articles in the four aforementioned databases. After discarding duplicates, 625 articles were considered for the analysis of titles and abstracts. Among these, however, only 39 met the eligibility criteria and their full texts were analyzed. After analyzing the methodologies used in the randomized clinical trials, another 28 articles were excluded. Among these, six involved treatments associating physical exercise with dietary prescriptions, four involved unsupervised exercise programs, three compared two aerobic exercise programs at different levels of intensity but did not include a control group, one applied a protocol of aerobic exercise combined with resistance exercise, and fourteen did not evaluate CRP and/or inflammatory cytokine plasma levels. In the end, eleven studies met the preestablished eligibility criteria and were therefore included in this review. A manual search of the references listed in these seven articles was performed, but no studies were found that met the eligibility criteria besides the ones already selected (Figure 1).

3.2. Characteristics of Included Studies. The eleven studies selected to be included in this review were randomized controlled trials published in English, which used aerobic or resistance exercise for the treatment of patients above 18 years of age diagnosed with T2DM. Among these studies, four were conducted in Greece, two in the United States, one in New Zealand, one in Brazil, one in Australia, one in Iran, and one in Germany.

Among these eleven studies, ten used control groups. Two of these control groups received placebo training, three were instructed to perform 150 minutes per week of low-intensity physical activities, one was offered low-intensity stretching exercises once a week, and two were told to keep up their routine daily activities. Two studies did not describe the characteristics of their control groups.

Eight studies used aerobic training, while seven studies used resistance training. Considering the methods employed, it was possible to compare control group versus aerobic training, control group versus resistance training, and aerobic training versus resistance training in seven, six, and four studies, respectively (Table 1). Table 2 describes the training programs and training intensities employed in these studies.

The seven studies included in this review involved 633 participants, all diagnosed with T2DM, who did not engage in regular physical activity. The plasma CRP levels were analyzed in ten studies (582 participants) before and after the full course of treatment.
Seven studies evaluated different inflammation-associated cytokines (Table 2): vaspin, human apelin-12, visfatin, ghrelin, adiponectin, resistin, tumor necrosis factor- $\alpha$ (TNF$\alpha$ ), interleukin-6 (IL-6), IL-10, and IL-18. All included studies were considered on descriptive analysis and discussion of the results.

3.3. Meta-Analysis. The design of this systematic review included a meta-analysis of plasma CRP and cytokine levels. However, upon reviewing the studies, it was impossible to perform this statistical procedure for the following reasons [19]:

(1) Seven studies presented pre- and posttreatment analytical data [20-25], while four reported pre- and posttreatment delta variations [26-29] and three studies presented some results in a graph form, without providing data that would enable this analysis $[23,24,26]$.

(2) Eight studies presented their data as mean values \pm standard deviations $[22-27,29,30]$, one as mean \pm standard error of the mean [21], another as median \pm standard deviation [20], and one as mean and confidence interval [28].

(3) The CRP data were expressed in different units of measure ( $\mathrm{mmol} / \mathrm{l}, \mathrm{mg} / \mathrm{l}, \mathrm{mg} / \mathrm{l}, \mathrm{pg} / \mathrm{ml}$, and $\log$ ).

(4) The studies measured plasma levels of different cytokines. When more than one study analyzed the same cytokine, the above-described problems precluded the implementation of the meta-analysis.

The authors were asked via email to provide data required to perform the meta-analysis, but only one group [24] answered and sent the requested data.

After attempting to combine the studies to proceed with the meta-analysis, only two studies in each exercise modality were eligible for statistical analysis. This kind of analysis could not be able to translate the effect of interventions and was disconsidered.

3.4. Assessment of Heterogeneity. The sample of ten studies was composed of individuals of both sexes, albeit with a predominance of women. Moghadasi et al.s (2013) [30] study had a sample composed of just men. The average age of the participants showed a little variation between the RCTs, with averages ranging from 48 to 68 years of age. On the other 
TABLE 2: Description of training programs employed in the treatment of participants in randomized clinical trials.

\begin{tabular}{|c|c|c|c|c|c|c|c|}
\hline $\begin{array}{l}\text { Author, } \\
\text { year }\end{array}$ & Country & Participants & $\begin{array}{l}\text { Interventions, } \\
\text { group }(n)\end{array}$ & $\begin{array}{l}\text { Intervention } \\
\text { period }\end{array}$ & $\begin{array}{l}\text { Inflammatory } \\
\text { status variables } \\
\text { analyzed }\end{array}$ & Results & Remarks \\
\hline $\begin{array}{l}\text { Brooks et } \\
\text { al., } 2007 \\
{[20]}\end{array}$ & $\begin{array}{l}\text { United } \\
\text { States }\end{array}$ & $\begin{array}{l}\text { Hispanic man } \\
\text { and woman, } 55 \\
\text { years old and } \\
\text { older with } \\
\text { diagnosed } \\
\text { T2DM }\end{array}$ & $\begin{array}{l}\text { Control (31): } \\
\text { recommended to } \\
\text { continue usual } \\
\text { standard of care. } \\
\text { Resistance (31): } \\
60-80 \% \text { of } 1 \mathrm{RM} \\
\text { during the first } 9 \\
\text { weeks and } 70-80 \% \\
\text { of } 1 \mathrm{RM} \text { on weeks } \\
10-16 .\end{array}$ & $\begin{array}{l}45 \mathrm{~min} / \text { session, } \\
3 \mathrm{x} / \text { week, } \\
\text { for } 4 \text { months }\end{array}$ & $\begin{array}{l}\text { CRP }(\mathrm{mg} / \mathrm{l}) \\
\text { Adiponectin } \\
(\mu \mathrm{g} / \mathrm{ml})\end{array}$ & $\begin{array}{l}\text { Reduction in serum } \\
\text { CRP level in } \\
\text { resistance training } \\
\text { group compared with } \\
\text { control group. } \\
\text { Increase in } \\
\text { adiponectin } \\
\text { concentrations in } \\
\text { resistance group } \\
\text { compared with } \\
\text { control group. }\end{array}$ & $\begin{array}{l}\text { Data from CRP } \\
\text { and adiponectin } \\
\text { were exposed as } \\
\text { median and } \\
\text { interquartile range }\end{array}$ \\
\hline
\end{tabular}

control group.

Reduction in hsCRP

and interleukin-18

after aerobic training

compared with

\begin{tabular}{|c|c|c|c|}
\hline $\begin{array}{l}\text { Kadoglou } \\
\text { et al., } 2007 \\
{[26]}\end{array}$ & Greece & $\begin{array}{l}\text { Man and } \\
\text { woman } \\
\text { with diagnosed } \\
\text { T2DM }\end{array}$ & $\begin{array}{l}\text { Control (30): no } \\
\text { programmed } \\
\text { activity. } \\
\text { Aerobic (30): } \\
50-75 \% \text { of } \\
\text { maximum } \mathrm{O}_{2} \\
\text { consumption. }\end{array}$ \\
\hline
\end{tabular}

$60 \mathrm{~min} / \mathrm{session}$,

$4 \mathrm{x} /$ week, for 6 months

hsCRP (mg/dl) control group.

Adiponectin Increase in

$(\mu \mathrm{g} / \mathrm{ml})$

interleukin-10 after

TNF- $\alpha(\mathrm{pg} / \mathrm{ml}) \quad$ aerobic training

Interleukin-18 compared with

(pg/ml)

Interleukin-10

(pg/ml)

control group.

Nonsignificant

changes in TNF- $\alpha$ or adiponectin in either

group or between the

groups after the

intervention.

Reduction in hsCRP

$\begin{array}{ll} & \text { Man and } \\ \text { Oberbach } & \text { woman } \\ \text { et al., 2008 Germany } & \text { with glucose } \\ \text { [21] } & \text { impaired } \\ & \text { tolerance }\end{array}$

Control (16): not described.

Aerobic (24): load

not described.

$60 \mathrm{~min} / \mathrm{session}, \mathrm{hsCRP}(\mathrm{pg} / \mathrm{ml})$

$2 \mathrm{x} /$ week, Interleukin-6

for 12 months $\quad(\mathrm{pg} / \mathrm{ml})$

and interleukin-6

serum level in the

aerobic group after

intervention.

Data from hsCRP, adiponectin, TNF- $\alpha$, interleukin-10, and interleukin-18 were exposed on graphs without values of mean and standard deviation.

Data before and after intervention exposed on analytical values (mean \pm standard error of mean).

\begin{tabular}{|c|c|c|c|c|c|c|c|}
\hline $\begin{array}{l}\text { Jorge et al., } \\
2011 \text { [22] }\end{array}$ & Brazil & $\begin{array}{l}\text { Man and } \\
\text { woman } \\
\text { aged } 30-70 \\
\text { years } \\
\text { diagnosed with } \\
\text { T2DM and with } \\
\text { body mass index } \\
\text { between } 25 \text { and } \\
40 \mathrm{~kg} / \mathrm{m}^{2}\end{array}$ & $\begin{array}{l}\text { Control (12): light } \\
\text { stretching exercise. } \\
\text { Aerobic (12): up to } \\
\text { lactate threshold. } \\
\text { Resistance (12): } \\
\text { load not described. } \\
\text { Combination (12): } \\
\text { aerobic and } \\
\text { resistance training } \\
\text { with the same } \\
\text { intensity of the } \\
\text { other training } \\
\text { groups and half of } \\
\text { the exercise } \\
\text { volume on each } \\
\text { category. }\end{array}$ & $\begin{array}{l}60 \mathrm{~min} / \text { session, } \\
3 \mathrm{x} / \text { week, } \\
\text { for } 3 \text { months }\end{array}$ & $\begin{array}{l}\text { hsCRP }(\mathrm{mg} / \mathrm{ml}) \\
\text { Adiponectin } \\
(\mu \mathrm{g} / \mathrm{ml}) \\
\text { Visfatin }(\mathrm{ng} / \mathrm{ml}) \\
\text { Resistin }(\mathrm{ng} / \mathrm{ml}) \\
\text { TNF- } \alpha(\mathrm{pg} / \mathrm{ml}) \\
\text { Interleukin -6 } \\
(\mathrm{pg} / \mathrm{ml})\end{array}$ & $\begin{array}{l}\text { Reduction in hsCRP } \\
\text { serum level in all } \\
\text { groups, including } \\
\text { control after } \\
\text { intervention. } \\
\text { Increase in visfatin } \\
\text { serum level in all } \\
\text { groups, including } \\
\text { control after } \\
\text { intervention. } \\
\text { Nonsignificant } \\
\text { changes in } \\
\text { adiponectin, resistin, } \\
\text { TNF- } \alpha \text {, or } \\
\text { interleukin-6 in either } \\
\text { group after } \\
\text { intervention. }\end{array}$ & $\begin{array}{l}\text { Data before and } \\
\text { after intervention } \\
\text { exposed on } \\
\text { analytical values } \\
\text { (mean } \pm \text { standard } \\
\text { deviation). }\end{array}$ \\
\hline $\begin{array}{l}\text { Kadoglou } \\
\text { et al., } 2012 \\
{[23]}\end{array}$ & Greece & $\begin{array}{l}\text { Man and } \\
\text { woman } \\
\text { aged } 50-70 \\
\text { years } \\
\text { with a diagnosis } \\
\text { of T2DM }\end{array}$ & $\begin{array}{l}\text { Control (27): } 150 \\
\text { minutes/week of } \\
\text { self-managed } \\
\text { physical activity. } \\
\text { Aerobic (26): } \\
\text { progressive load } \\
\text { until } 60 \%-75 \% \text { of } \\
\mathrm{HR}_{\max } .\end{array}$ & $\begin{array}{l}60 \mathrm{~min} / \text { session, } \\
4 \mathrm{x} / \text { week, } \\
\text { for } 3 \text { months }\end{array}$ & $\begin{array}{l}\text { Human } \\
\text { apelin-12 } \\
(\mathrm{ng} / \mathrm{ml}) \\
\text { Ghrelin (ng/ml) }\end{array}$ & $\begin{array}{l}\text { Increment on apelin } \\
\text { serum level after the } \\
\text { intervention period } \\
\text { on aerobic training } \\
\text { group compared with } \\
\text { control group. } \\
\text { Nonsignificant effect } \\
\text { on ghrelin serum } \\
\text { level in the } \\
\text { intervention group. }\end{array}$ & $\begin{array}{l}\text { Data from apelin } \\
\text { and ghrelin were } \\
\text { exposed on graphs } \\
\text { without values of } \\
\text { mean and standard } \\
\text { deviation. }\end{array}$ \\
\hline
\end{tabular}


TABLE 2: Continued.

\begin{tabular}{|c|c|c|c|c|c|c|c|}
\hline $\begin{array}{l}\text { Author, } \\
\text { year }\end{array}$ & Country & Participants & $\begin{array}{l}\text { Interventions, } \\
\text { group }(n)\end{array}$ & $\begin{array}{l}\text { Intervention } \\
\text { period }\end{array}$ & $\begin{array}{l}\text { Inflammatory } \\
\text { status variables } \\
\text { analyzed }\end{array}$ & Results & Remarks \\
\hline $\begin{array}{l}\text { Kadoglou } \\
\text { et al., } 2012 \\
{[27]}\end{array}$ & Greece & $\begin{array}{l}\text { Man and } \\
\text { woman with } \\
\text { T2DM } \\
\text { diagnosed for } \\
\text { more than } 1 \text { year }\end{array}$ & $\begin{array}{l}\text { Control (24): } 150 \\
\text { minutes/week of } \\
\text { self-managed } \\
\text { physical activity. } \\
\text { Resistance (23): 2-3 } \\
\text { sets of 6-8 } \\
\text { repetitions on } \\
\text { machine weights. } \\
\text { Exercise intensity } \\
\text { of } 60-80 \% \text { of 1RM. }\end{array}$ & $\begin{array}{l}60 \mathrm{~min} / \text { session, } \\
3 \mathrm{x} / \text { week, } \\
\text { for } 3 \text { months }\end{array}$ & hsCRP (mg/l) & $\begin{array}{l}\text { Nonsignificant } \\
\text { changes in CRP levels } \\
\text { between the groups } \\
\text { after the intervention. }\end{array}$ & $\begin{array}{l}\text { Data expressed as } \\
\text { delta variation } \\
\text { (mean } \pm \text { standard } \\
\text { deviation). }\end{array}$ \\
\hline $\begin{array}{l}\text { Sukala et } \\
\text { al., } 2012 \\
{[24]}\end{array}$ & $\begin{array}{c}\text { New } \\
\text { Zealand }\end{array}$ & $\begin{array}{l}\text { Man and } \\
\text { woman } \\
\text { self-identified } \\
\text { Polynesian } \\
\text { descent, with } \\
\text { clinical } \\
\text { diagnosis of } \\
\text { T2DM and } \\
\text { visceral obesity }\end{array}$ & $\begin{array}{l}\text { Aerobic (9): } \\
65-80 \% \text { of heart } \\
\text { rate reserve } \\
\left(\mathrm{HR}_{\text {reserve }}\right) \text {. } \\
\text { Resistance (9): } \\
\text { progressive load } \\
(5 \%) \text { starting from } \\
\text { the execution of } 10 \\
\text { repetitions. }\end{array}$ & $\begin{array}{l}40 \text { to } \\
60 \mathrm{~min} / \text { session, } \\
3 \mathrm{x} / \mathrm{week} \text {, } \\
\text { for } 4 \text { months }\end{array}$ & $\begin{array}{l}\text { CRP }(\log ) \\
\text { Adiponectin } \\
(\mu \mathrm{g} / \mathrm{ml})\end{array}$ & $\begin{array}{l}\text { Nonsignificant } \\
\text { changes in CRP or } \\
\text { adiponectin in either } \\
\text { group or between the } \\
\text { groups after the } \\
\text { intervention. }\end{array}$ & $\begin{array}{l}\text { Data expressed as } \\
\text { delta variation } \\
\text { (mean } \pm \text { standard } \\
\text { deviation). }\end{array}$ \\
\hline $\begin{array}{l}\text { Swift et al., } \\
2012 \text { [28] }\end{array}$ & $\begin{array}{l}\text { United } \\
\text { States }\end{array}$ & $\begin{array}{l}\text { Man and } \\
\text { woman aged } \\
35-70 \text { years } \\
\text { with diagnosed } \\
\text { T2DM }\end{array}$ & $\begin{array}{l}\text { Control (37): } \\
\text { weekly stretching } \\
\text { and relaxation. } \\
\text { Aerobic (50): } \\
\text { 50-80\% of } \\
\text { maximum } \mathrm{O}_{2} \\
\text { consumption. } \\
\text { Resistance (58): } \\
\text { progressive load } \\
\text { starting from the } \\
\text { execution of } 12 \\
\text { repetitions. } \\
\text { Combination (59): } \\
\text { combination of } \\
\text { aerobic training } \\
\text { (10 kcal/kg/week) } \\
\text { plus } 2 \text { sessions of } \\
\text { resistance training } \\
\text { per week. }\end{array}$ & $\begin{array}{l}150 \mathrm{~min} / \text { week, } \\
3 \mathrm{x} / \text { week, } \\
\text { for } 9 \text { months }\end{array}$ & $\mathrm{CRP}(\mathrm{mg} / \mathrm{l})$ & $\begin{array}{l}\text { Nonsignificant } \\
\text { change in CRP serum } \\
\text { level in either group } \\
\text { or between the groups } \\
\text { after the intervention. }\end{array}$ & $\begin{array}{l}\text { Data expressed as } \\
\text { delta variation } \\
\text { (mean } \pm \\
\text { confidence } \\
\text { interval). }\end{array}$ \\
\hline $\begin{array}{l}\text { Kadoglou } \\
\text { et al., } 2013 \\
{[29]}\end{array}$ & Greece & $\begin{array}{l}\text { Man and } \\
\text { woman with } \\
\text { T2DM } \\
\text { diagnosed } \\
\text { for more than } 1 \\
\text { year. }\end{array}$ & $\begin{array}{l}\text { Control (24): } 150 \\
\text { minutes/week of } \\
\text { self-managed } \\
\text { physical activity. } \\
\text { Aerobic (21): } \\
\text { progressive load } \\
\text { until } 60 \%-75 \% \text { of } \\
\mathrm{HR}_{\max } \text {. } \\
\text { Resistance (23): } \\
\text { load of } 60 \%-80 \% \\
\text { of 1-MR. } \\
\text { Combination (22): } \\
\text { aerobic and } \\
\text { resistance training } \\
\text { with the same } \\
\text { intensity of the } \\
\text { other training } \\
\text { groups and half of } \\
\text { the exercise } \\
\text { volume on each } \\
\text { category. }\end{array}$ & $\begin{array}{l}60 \mathrm{~min} / \text { session, } \\
4 \mathrm{x} / \text { week, } \\
\text { for } 6 \text { months }\end{array}$ & $\begin{array}{l}\text { hsCRP }(\mathrm{mmol} / \mathrm{l}) \\
\text { Vaspin }(\mathrm{ng} / \mathrm{ml}) \\
\text { Human } \\
\text { apelin-12 } \\
(\mathrm{ng} / \mathrm{ml}) \\
\text { Visfatin }(\mathrm{ng} / \mathrm{ml}) \\
\text { Ghrelin }(\mathrm{ng} / \mathrm{ml})\end{array}$ & $\begin{array}{l}\text { Reduction in hsCRP } \\
\text { and visfatin serum } \\
\text { level after aerobic and } \\
\text { combined training } \\
\text { compared with both } \\
\text { resistance training } \\
\text { alone and control } \\
\text { groups. } \\
\text { Increment on apelin } \\
\text { and vaspin serum } \\
\text { level in the aerobic } \\
\text { exercise and } \\
\text { combined groups } \\
\text { rather than in the } \\
\text { control and resistance } \\
\text { training groups. } \\
\text { Nonsignificant effect } \\
\text { on ghrelin serum } \\
\text { level in the } \\
\text { intervention groups. }\end{array}$ & $\begin{array}{l}\text { Data from vaspin, } \\
\text { apelin, visfatin, and } \\
\text { ghrelin were } \\
\text { exposed on graphs } \\
\text { without values of } \\
\text { mean and standard } \\
\text { deviation. }\end{array}$ \\
\hline
\end{tabular}


TABLE 2: Continued.

\begin{tabular}{|c|c|c|c|c|c|c|c|}
\hline $\begin{array}{l}\text { Author, } \\
\text { year }\end{array}$ & Country & Participants & $\begin{array}{l}\text { Interventions, } \\
\text { group }(n)\end{array}$ & $\begin{array}{l}\text { Intervention } \\
\text { period }\end{array}$ & $\begin{array}{l}\text { Inflammatory } \\
\text { status variables } \\
\text { analyzed }\end{array}$ & Results & Remarks \\
\hline $\begin{array}{l}\text { Moghadasi } \\
\text { et al., } 2013 \\
{[30]}\end{array}$ & Iran & $\begin{array}{l}\text { Obese and } \\
\text { overweight man } \\
\text { with T2DM }\end{array}$ & $\begin{array}{l}\text { Control (8): not } \\
\text { described. } \\
\text { Aerobic (8): } \\
40-59 \% \text { of } \\
\text { maximum } \mathrm{O}_{2} \\
\text { consumption. }\end{array}$ & $\begin{array}{l}30 \mathrm{~min} / \mathrm{session}, \\
4 \mathrm{x} / \text { week, } \\
\text { for } 3 \text { months }\end{array}$ & $\begin{array}{l}\text { hsCRP }(\mathrm{mg} / \mathrm{ml}) \\
\text { Adiponectin } \\
(\mu \mathrm{g} / \mathrm{l})\end{array}$ & $\begin{array}{l}\text { Nonsignificant } \\
\text { changes } \\
\text { in CRP in either } \\
\text { group or between the } \\
\text { groups after the } \\
\text { intervention. } \\
\text { Adiponectin level } \\
\text { increased in training } \\
\text { group compared with } \\
\text { pretraining values. }\end{array}$ & - \\
\hline $\begin{array}{l}\text { Mavros et } \\
\text { al., } 2014 \\
{[25]}\end{array}$ & Australia & $\begin{array}{l}\text { Man and } \\
\text { woman } \geq 60 \\
\text { years of age, } \\
\text { sedentary with } \\
\text { type } 2 \text { diabetes } \\
\text { and metabolic } \\
\text { syndrome }\end{array}$ & $\begin{array}{l}\text { Control (47): } \\
\text { training on the } \\
\text { same equipment } \\
\text { used by resistance } \\
\text { group, } 3 \text { times a } \\
\text { week, under } \\
\text { supervision from } \\
\text { the same trainers. } \\
\text { Exercise intensity } \\
\text { as low as possible } \\
\text { and not } \\
\text { progressing. } \\
\text { Resistance (41): } 3 \\
\text { sets of } 8 \\
\text { repetitions. } \\
\text { Exercise intensity } \\
\text { of } 80 \% \text { of } 1 \text { RM. }\end{array}$ & $\begin{array}{l}\text { Session duration } \\
\text { not informed, } \\
3 \mathrm{x} / \text { week, for } 12 \\
\text { months }\end{array}$ & $\mathrm{CRP}(\mathrm{mg} / \mathrm{l})$ & $\begin{array}{l}\text { Reduction in CRP in } \\
\text { resistance group } \\
\text { relative to control } \\
\text { group. }\end{array}$ & - \\
\hline
\end{tabular}

hand, the training programs varied significantly (Table 2). The duration of the exercise sessions was similar in seven studies (60 minutes). However, the frequency of training varied from 2 to 4 times per week. One of the studies did not report the duration and frequency of sessions, only the total workout time per week. Moreover, follow-up of the participants varied from three to twelve months.

The load applied in aerobic training sessions was defined based on different parameters: maximum heart rate, heart rate reserve, maximal oxygen uptake, and lactate threshold. Two studies did not report this load.

The intensity of resistance exercise was also variable: four studies used $60-80 \%$ of one maximum repetition, while two other studies considered the performance of a number of repetitions (10 or 12 repetitions) as the parameter of evaluation. One study did not describe the load applied in resistance training.

\section{Discussion}

The focus of this review was to investigate the effects of physical exercise on inflammatory markers. Analyzing the studies published until the selection procedure, we observed that the authors of the included RCTs used different training programs in their methodologies. Variations in time, frequency, and intensity of exercise impaired comparison between the studies. These are parameters that directly interfere in metabolic response to exercise [31-35] and comparisons between different treatments could be a source of bias. These facts prevented evidence from being gathered which would support or refute the hypothesis that physical exercise can improve the proinflammatory state of individuals with T2DM.

The studies that compare a group of individuals who performed aerobic exercise with a control group [21-23, 26, 28-30] present contradictory results about the effectiveness of training to reduce plasma CRP levels. While Kadaglou et al. [26], Oberbach et al. [21], and Kadaglou et al. [29] reported a reduction in the plasma CRP levels of trained individuals, three other studies found no significant difference in this parameter $[22,28,30]$ when comparing the control group versus the aerobic group after the intervention. It was not possible to identify a specific outcome of exercise that could be related to different results from these studies. The aerobic training protocols used similar time of session training (30-60 minutes), but the divergence appears regarding duration of patient follow-up, weekly workout frequency, and training intensity.

As for the evaluation of cytokines, the data reported in the analyzed studies are still incipient. The two studies that analyzed TNF- $\alpha[22,26]$ found no difference between the aerobic training group and the control group after the exercise protocol. There were no significant changes 
in adiponectin serum level in participants of two studies that evaluated this variable $[22,26]$. On the other hand, adiponectin levels increased in the aerobic training group compared with pretraining values in Moghadasi et al's study [30]. Two other RCTs $[23,29]$ assessed ghrelin plasmatic level, but no significant changes were found between the groups compared.

Conflicting results were observed in the analysis of IL6 and visfatin. Oberbach et al. [21] concluded that aerobic exercise reduces plasma levels of IL-6, while Jorge et al. [22] found no significant difference for this marker. Data of visfatin measurement demonstrated a reduction in participants of aerobic exercise program in comparison with controls [29]. On the other hand, Jorge et al. [22] found an increase in visfatin serum level in all groups, including control, after the follow-up period when compared with baseline measurements.

Increments on human apelin-12 serum level in the aerobic exercise group rather than in the control groups were found in two studies $[23,29]$, but both from the same population. Only one study evaluated serum level of resistin [22], vaspin [29], IL-18 [26], and IL-10 [26].

In studies comparing individuals in resistance training with a control group [20,22, 25, 27-29], the only variable of interest analyzed for all was CRP. Four studies reported finding no significant difference between the control and trained groups [22, 27-29] while two trials found a reduction in CRP serum level in resistance training groups when compared with the control group [20,25]. Visfatin serum level was analyzed in two studies $[19,22]$; in both, there were no significant changes after resistance exercise program when compared with the control group. Brooks et al. [20] reported reduction in adiponectin serum levels in the treated group compared with the control group while Kadoglou et al. [27] found no significant difference. Vaspin [29], human apelin-12 [29], ghrelin [29], resistin [22], TNF- $\alpha$ [22], and interleukin6 [22] were evaluated in just one of the six studies. This makes conclusive analysis impossible. Furthermore, such findings should be considered carefully because when resistance loads, weekly training frequency, and follow-up periods differ, there can be no reproducibility of results.

Among the studies that compared the two types of exercise (aerobic and resistance) [22, 24, 28, 29], only Kadaglou et al. [29] demonstrated that aerobic exercise decreased the CRP levels in comparison to those individuals undergoing resistance training. Also, in this study, an increment in apelin and vaspin was found after aerobic training in comparison with the resistance group. The studies found no difference in the levels of other cytokines (ghrelin [22, 29], adiponectin $[22,24]$, TNF- $\alpha$ [22], resistin [22], and IL-6 [22]) between the groups after the training protocol.

It is important to highlight that $\mathrm{T} 2 \mathrm{DM}$ is a disease with multifactorial etiology that affects many physiological systems. Because of this, the treatment must contemplate several strategies in order to promote the health of individuals with T2DM. Data from the Italian Diabetes and Exercise Study (IDES) [36-38] showed that aerobic or combined (aerobic and resistance) exercise was effective in reducing CRP plasma levels after 12 months of training in T2DM patients receiving standard medical care (nutritional guidance and pharmacological treatment). Similar results were observed in other inflammatory markers. Leptin, resistin, and interleukin- 6 decreased, whereas adiponectin increased in exercising groups [37]. Interleukin- $1 \beta$, tumor necrosis factor$\alpha$, and interferon- $\gamma$ decreased, whereas anti-inflammatory interleukin-4 and interleukin-10 increased only in the group that performed combined exercise [37].

On the other hand, even in studies with other treatments associated with exercise, the results are contradictory. While Choi et al. [39] demonstrated that CRP decreased in an exercising group of T2DM patients after 12 weeks, no significant differences were observed in interleukin-6. Byrkjeland et al. [40] found no difference in CRP plasma level from individuals in a training program or sedentary individuals.

It is interesting that changes in $\mathrm{VO}_{2}$ max, exercise modalities, and training supervision were strong predictors of inflammation reduction in IDES [36-38]. In the analyzed studies in this review, it is possible that divergences in results are related to characteristics of applied exercise. This reinforces the importance of individuality in the prescription of exercise program and the supervision of training by a professional.

In this review, two RCTs did not clearly state the intensity of aerobic exercise [21] and the load applied in resistance training [22]. This seriously compromises the systematic analysis of results, since training intensity implies different metabolic alterations $[33,34]$. Thus, the results of studies that used different training modalities and/or intensities cannot be compared.

Although this systematic review identified a sufficient number of RCTs to perform a meta-analysis, their methodological heterogeneity led to a careful analysis in terms of clinical applicability of the results, since they are from different interventions.

The presentation of data in different units of measure or in graph format (without numerical information on mean and standard deviation) prevented a statistical comparison of the results of most included studies. This showed us that there is no standardization in the presentation format of the biochemical data in the analyzed scientific articles, which makes an analysis to provide subsidies to refute or confirm the initial hypotheses of this systematic review difficult.

From the standpoint of clinical applicability, the studies show little power to endorse the recommendation of physical exercise as a strategy to reverse or control the inflammatory state in diabetes. However, previously published reviews have shown that exercise is effective for glycemic control $[34,35]$ and improved arterial function [41]. Therefore, the results of this review do not contraindicate the use of exercise in the nonpharmacological therapeutic management of diabetes, since there is evidence of benefits for other disorders presented by individuals with T2DM [34, 35, 41].

Limitations of this study were the presence of methodological heterogeneity in the studies selected for this metaanalysis, the lack of data that could be analyzed by metaanalysis, and the restriction of the selection to studies on T2DM. 


\section{Conclusions}

The evidence was insufficient to prove that aerobic or resistance training improves plasma levels of inflammatory markers in patients with T2DM. Thus, we recommend further studies designed with the methodological rigor necessary to prove or disprove the effectiveness of this strategy in reversing inflammation associated with T2DM.

To date, no other reviews have been published about the effects of physical exercise on inflammation in patients with T2DM. Thus, the systematic review of scientific literature on the subject in question provides supporting evidence to underpin new studies that can meet the methodological requirements for the establishment of scientific evidence.

\begin{tabular}{|c|c|}
\hline 1-MR: & One maximum repetition \\
\hline CRP: & C-reactive protein \\
\hline DM: & Diabetes mellitus \\
\hline GLUT4: & Glucose transporter 4 \\
\hline HDL: & High-density lipoprotein \\
\hline $\mathrm{HR}_{\max }$ : & Maximum heart rate \\
\hline IL: & Interleukin \\
\hline PRISMA: & $\begin{array}{l}\text { Preferred Reporting Items for Systematic } \\
\text { Reviews and Meta-Analyses }\end{array}$ \\
\hline RCT: & Randomized controlled trial \\
\hline T2DM: & Type 2 diabetes mellitus \\
\hline TNF- $\alpha:$ & Tumor necrosis factor-alpha. \\
\hline
\end{tabular}

\section{Conflicts of Interest}

The authors have declared that no conflicts of interest exist regarding the publication of this paper.

\section{Authors' Contributions}

Luciana Costa Melo, Jaime Dativo-Medeiros, Carlos Eduardo Menezes-Silva, Fabiano Timbó Barbosa, and Luiza A. Rabelo wrote the manuscript. Fabiano Timbó Barbosa, Célio Fernando de Sousa-Rodrigues, Luciana Costa Melo, and Luiza A. Rabelo revised the paper. Luiza A. Rabelo edited the manuscript. All authors had full access to the study data and approved the final version.

\section{Acknowledgments}

The authors wish to thank Coordenação de Aperfeiçoamento de Pessoal de Nível Superior (CAPES) Conselho Nacional de Desenvolvimento Científico e Tecnológico (CNPq) and Fundação de Amparo à Pesquisa de Alagoas (FAPEAL) for financial support. Luciana Costa Melo was supported by a Ph.D. student fellowship from CAPES and Carlos Eduardo Menezes-Silva received a Masters Scholarship from CAPES. The authors would like to thank Valéria Nunes-Souza, of the Federal University of Pernambuco, for the helpful discussions.

\section{References}

[1] W. Kerner and J. Brückel, "Definition, classification and diagnosis of diabetes mellitus," Experimental and Clinical Endocrinology and Diabetes, vol. 122, no. 7, pp. 384-386, 2014.

[2] S. Wild, G. Roglic, A. Green, R. Sicree, and H. King, "Global prevalence of diabetes: estimates for the year 2000 and projections for 2030," Diabetes Care, vol. 27, no. 5, pp. 1047-1053, 2004.

[3] WHO, "Diabetes," October 2013, http://www.who.int/mediacentre/factsheets/fs312/en/.

[4] K. G. M. M. Alberti, P. Zimmet, and J. Shaw, "The metabolic syndrome-a new worldwide definition," The Lancet, vol. 366, no. 9491, pp. 1059-1062, 2005.

[5] K. N. Keane, V. F. Cruzat, R. Carlessi, P. I. H. De Bittencourt, and P. Newsholme, "Molecular events linking oxidative stress and inflammation to insulin resistance and $\beta$-cell dysfunction," Oxidative Medicine and Cellular Longevity, vol. 2015, Article ID 181643, 15 pages, 2015.

[6] F. K. Welty, A. Alfaddagh, and T. K. Elajami, "Targeting inflammation in metabolic syndrome," Translational Research, vol. 167, no. 1, pp. 257-280, 2016.

[7] M. Y. Donath and S. E. Shoelson, "Type 2 diabetes as an inflammatory disease," Nature Reviews Immunology, vol. 11, no. 2, pp. 98-107, 2011.

[8] C. Herder, T. Illig, W. Rathmann et al., "Inflammation and type 2 diabetes: results from KORA Augsburg," Gesundheitswesen, vol. 67, pp. 115-121, 2005.

[9] C. Herder, E. J. Brunner, W. Rathmann et al., "Elevated levels of the anti-inflammatory interleukin-1 receptor antagonist precede the onset of type 2 diabetes: the whitehall II study," Diabetes Care, vol. 32, no. 3, pp. 421-423, 2009.

[10] J. Spranger, A. Kroke, M. Möhlig et al., "Inflammatory cytokines and the risk to develop type 2 diabetes: results of the prospective population-based European Prospective Investigation into Cancer and Nutrition (EPIC)-Potsdam study," Diabetes, vol. 52, no. 3, pp. 812-817, 2003.

[11] S. R. Colberg, R. J. Sigal, B. Fernhall et al., "Exercise and type 2 diabetes: The American College Of Sports Medicine and The American Diabetes Association: joint position statement executive summary," Diabetes Care, vol. 33, no. 12, pp. 26922696, 2010.

[12] D. Umpierre, P. A. B. Ribeiro, C. K. Kramer et al., "Physical activity advice only or structured exercise training and association with HbAlc levels in type 2 diabetes: a systematic review and meta-analysis," JAMA-Journal of the American Medical Association, vol. 305, no. 17, pp. 1790-1799, 2011.

[13] V. S. Conn, R. J. Koopman, T. M. Ruppar, L. J. Phillips, D. R. Mehr, and A. R. Hafdahl, "Insulin sensitivity following exercise interventions: systematic review and meta-analysis of outcomes among healthy adults," Journal of Primary Care and Community Health, vol. 5, no. 3, pp. 211-222, 2014.

[14] American Diabetes Association, "Physical activity/exercise and diabetes," Diabetes Care, vol. 27, S1, pp. S58-S62, 2004.

[15] P. Araiza, H. Hewes, C. Gashetewa, C. A. Vella, and M. R. Burge, "Efficacy of a pedometer-based physical activity program on parameters of diabetes control in type 2 diabetes mellitus," Metabolism: Clinical and Experimental, vol. 55, no. 10, pp. 13821387, 2006.

[16] E. Ravussin and S. R. Smith, "Increased fat intake, impaired fat oxidation, and failure of fat cell proliferation result in ectopic fat storage, insulin resistance, and type 2 diabetes mellitus," Annals of the New York Academy of Sciences, vol. 967, pp. 363-378, 2002. 
[17] “Standards of medical care in diabetes-2012," Diabetes Care, vol. 35, supplement 1, pp. S11-S63, 2011.

[18] D. Moher, A. Liberati, J. Tetzlaff et al., "Preferred reporting items for systematic reviews and meta-analyses: The PRISMA statement," Annals of Internal Medicine, vol. 151, no. 4, pp. 264269, 2009.

[19] J. J. Deeks, J. P. T. Higgins, and D. G. Altman, "General methods for Cochrane reviews: analysing data and undertaking metaanalyses," http://handbook.cochrane.org/chapter_9/9_analysing_data_and_undertaking_meta_analyses.htm.

[20] N. Brooks, J. E. Layne, P. L. Gordon, R. Roubenoff, M. E. Nelson, and C. Castaneda-Sceppa, "Strength training improves muscle quality and insulin sensitivity in Hispanic older adults with type 2 diabetes," International Journal of Medical Sciences, vol. 4, no. 1, pp. 19-27, 2007.

[21] A. Oberbach, S. Lehmann, K. Kirsch et al., "Long-term exercise training decreases interleukin-6 (IL-6) serum levels in subjects with impaired glucose tolerance: effect of the $-174 \mathrm{G} / \mathrm{C}$ variant in IL-6 gene," European Journal of Endocrinology, vol. 159, no. 2, pp. 129-136, 2008.

[22] M. L. M. P. Jorge, V. N. De Oliveira, N. M. Resende et al., "The effects of aerobic, resistance, and combined exercise on metabolic control, inflammatory markers, adipocytokines, and muscle insulin signaling in patients with type 2 diabetes mellitus," Metabolism: Clinical and Experimental, vol. 60, no. 9, pp. 1244-1252, 2011.

[23] N. P. E. Kadoglou, I. S. Vrabas, A. Kapelouzou et al., "The impact of aerobic exercise training on novel adipokines, apelin and ghrelin, in patients with type 2 diabetes," Medical Science Monitor, vol. 18, no. 5, pp. CR290-CR295, 2012.

[24] W. R. Sukala, R. Page, D. S. Rowlands et al., "South Pacific Islanders resist type 2 diabetes: comparison of aerobic and resistance training," European Journal of Applied Physiology, vol. 112, no. 1, pp. 317-325, 2012.

[25] Y. Mavros, S. Kay, K. A. Simpson et al., "Reductions in Creactive protein in older adults with type 2 diabetes are related to improvements in body composition following a randomized controlled trial of resistance training," Journal of Cachexia, Sarcopenia and Muscle, vol. 5, no. 2, pp. 111-120, 2014.

[26] N. P. E. Kadoglou, F. Iliadis, N. Angelopoulou et al., "The anti-inflammatory effects of exercise training in patients with type 2 diabetes mellitus," European Journal of Cardiovascular Prevention and Rehabilitation, vol. 14, no. 6, pp. 837-843, 2007.

[27] N. P. E. Kadoglou, G. Fotiadis, Z. Athanasiadou, I. Vitta, S. Lampropoulos, and I. S. Vrabas, "The effects of resistance training on ApoB/ApoA-I ratio, Lp(a) and inflammatory markers in patients with type 2 diabetes," Endocrine, vol. 42, no. 3, pp. 561569, 2012.

[28] D. L. Swift, N. M. Johannsen, C. P. Earnest, S. N. Blair, and T. S. Church, "Effect of exercise training modality on C-reactive protein in type 2 diabetes," Medicine and Science in Sports and Exercise, vol. 44, no. 6, pp. 1028-1034, 2012.

[29] N. P. E. Kadoglou, G. Fotiadis, A. Kapelouzou, A. Kostakis, C. D. Liapis, and I. S. Vrabas, "The differential anti-inflammatory effects of exercise modalities and their association with early carotid atherosclerosis progression in patients with Type 2 diabetes," Diabetic Medicine, vol. 30, no. 2, pp. e41-e50, 2013.

[30] M. Moghadasi, H. Mohebbi, F. Rahmani-Nia, S. HassanNia, and H. Noroozi, "Effects of short-term lifestyle activity modification on adiponectin mRNA expression and plasma concentrations," European Journal of Sport Science, vol. 13, no. 4, pp. 378-385, 2013.
[31] J. M. Peake, S. J. Tan, J. F. Markworth, J. A. Broadbent, T. L. Skinner, and D. Cameron-Smith, "Metabolic and hormonal responses to isoenergetic high-intensity interval exercise and continuous moderate-intensity exercise," AJP: Endocrinology and Metabolism, vol. 307, no. 7, pp. E539-E552, 2014.

[32] H. Arazi, B. Mirzaei, and N. Heidari, "Neuromuscular and metabolic responses to three different resistance exercise methods," Asian Journal of Sports Medicine, vol. 5, no. 1, pp. 30-38, 2014.

[33] N. Argani, G. Sharifi, and J. Golshahi, "Comparison of the effect of different intensity exercise on a bicycle ergometer on postprandial lipidemia in type II diabetic patients," ARYA Atherosclerosis, vol. 10, no. 3, pp. 147-153, 2014.

[34] D. Umpierre, P. A. B. Ribeiro, B. D. Schaan, and J. P. Ribeiro, "Volume of supervised exercise training impacts glycaemic control in patients with type 2 diabetes: a systematic review with meta-regression analysis," Diabetologia, vol. 56, no. 2, pp. 242251, 2013.

[35] C. Irvine and N. F. Taylor, "Progressive resistance exercise improves glycaemic control in people with type 2 diabetes mellitus: a systematic review," The Australian Journal of Physiotherapy, vol. 55, no. 4, pp. 237-246, 2009.

[36] S. Balducci, S. Zanuso, P. Cardelli et al., "Supervised exercise training counterbalances the adverse effects of insulin therapy in overweight/obese subjects with type 2 diabetes," Diabetes Care, vol. 35, no. 1, pp. 39-41, 2012.

[37] S. Balducci, S. Zanuso, A. Nicolucci et al., "Anti-inflammatory effect of exercise training in subjects with type 2 diabetes and the metabolic syndrome is dependent on exercise modalities and independent of weight loss," Nutrition, Metabolism and Cardiovascular Diseases, vol. 20, no. 8, pp. 608-617, 2010.

[38] S. Balducci, S. Zanuso, P. Cardelli et al., "Effect of high- versus low-intensity supervised aerobic and resistance training on modifiable cardiovascular risk factors in Type 2 diabetes; The Italian Diabetes and Exercise Study (IDES)," PLoS ONE, vol. 7, no. 11, Article ID e49297, 2012.

[39] K. M. Choi, K. A. Han, H. J. Ahn et al., "Effects of exercise on sRAGE levels and cardiometabolic risk factors in patients with type 2 diabetes: a randomized controlled trial," Journal of Clinical Endocrinology and Metabolism, vol. 97, no. 10, pp. 37513758, 2012.

[40] R. Byrkjeland, I. U. Njerve, S. Anderssen, H. Arnesen, I. Seljeflot, and S. Solheim, "Effects of exercise training on $\mathrm{HbA}_{1 c}$ and $\mathrm{VO}_{2 \text { peak }}$ in patients with type 2 diabetes and coronary artery disease: a randomised clinical trial," Diabetes and Vascular Disease Research, vol. 12, no. 5, pp. 325-333, 2015.

[41] D. Montero, G. Walther, E. Benamo, A. Perez-Martin, and A. Vinet, "Effects of exercise training on arterial function in type 2 diabetes mellitus: a systematic review and meta-analysis," Sports Medicine, vol. 43, no. 11, pp. 1191-1199, 2013. 


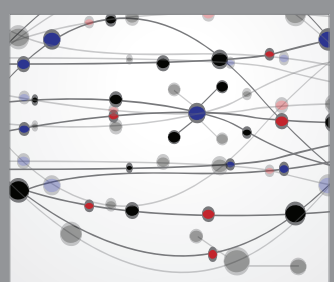

The Scientific World Journal
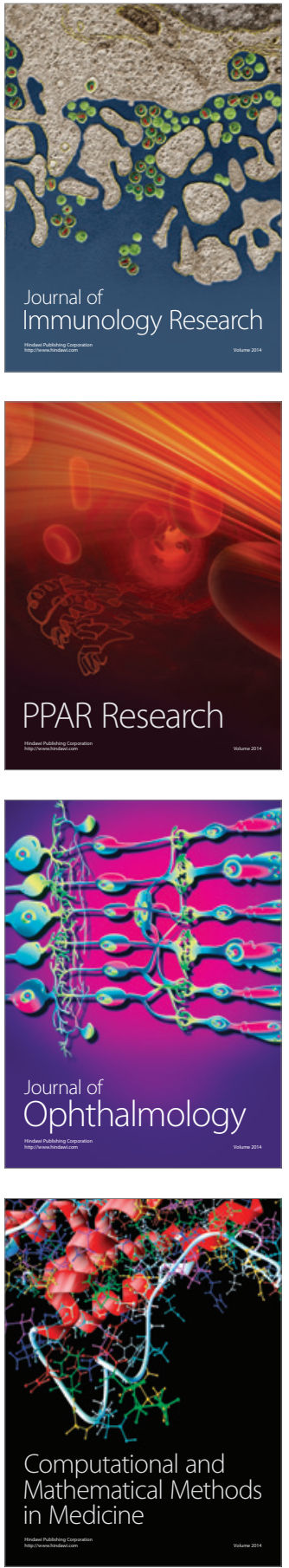

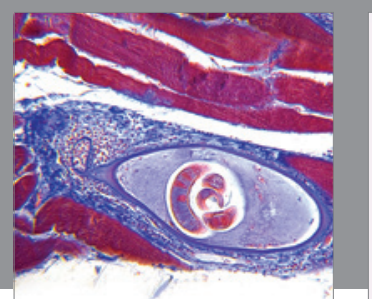

Gastroenterology Research and Practice
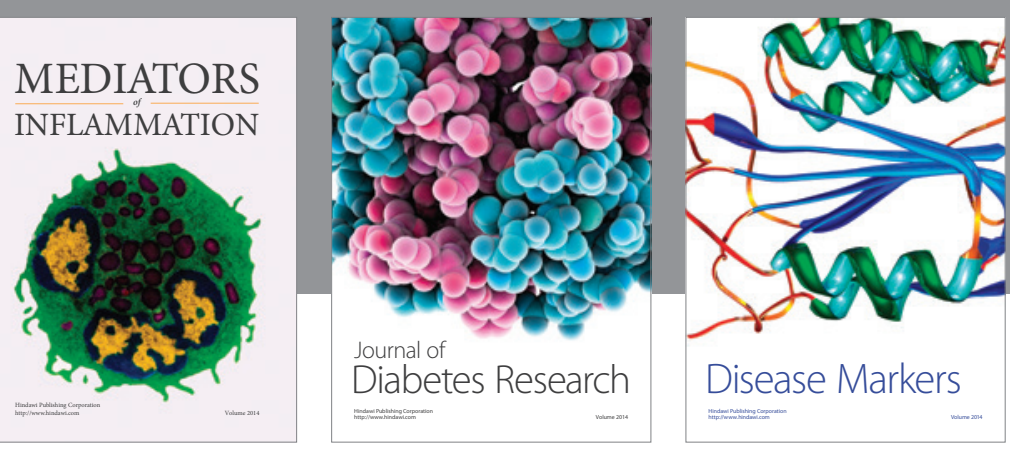

Disease Markers

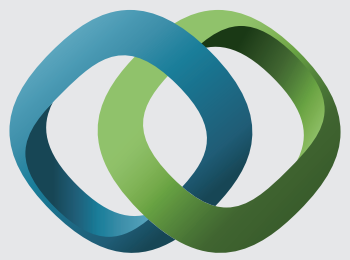

\section{Hindawi}

Submit your manuscripts at

https://www.hindawi.com
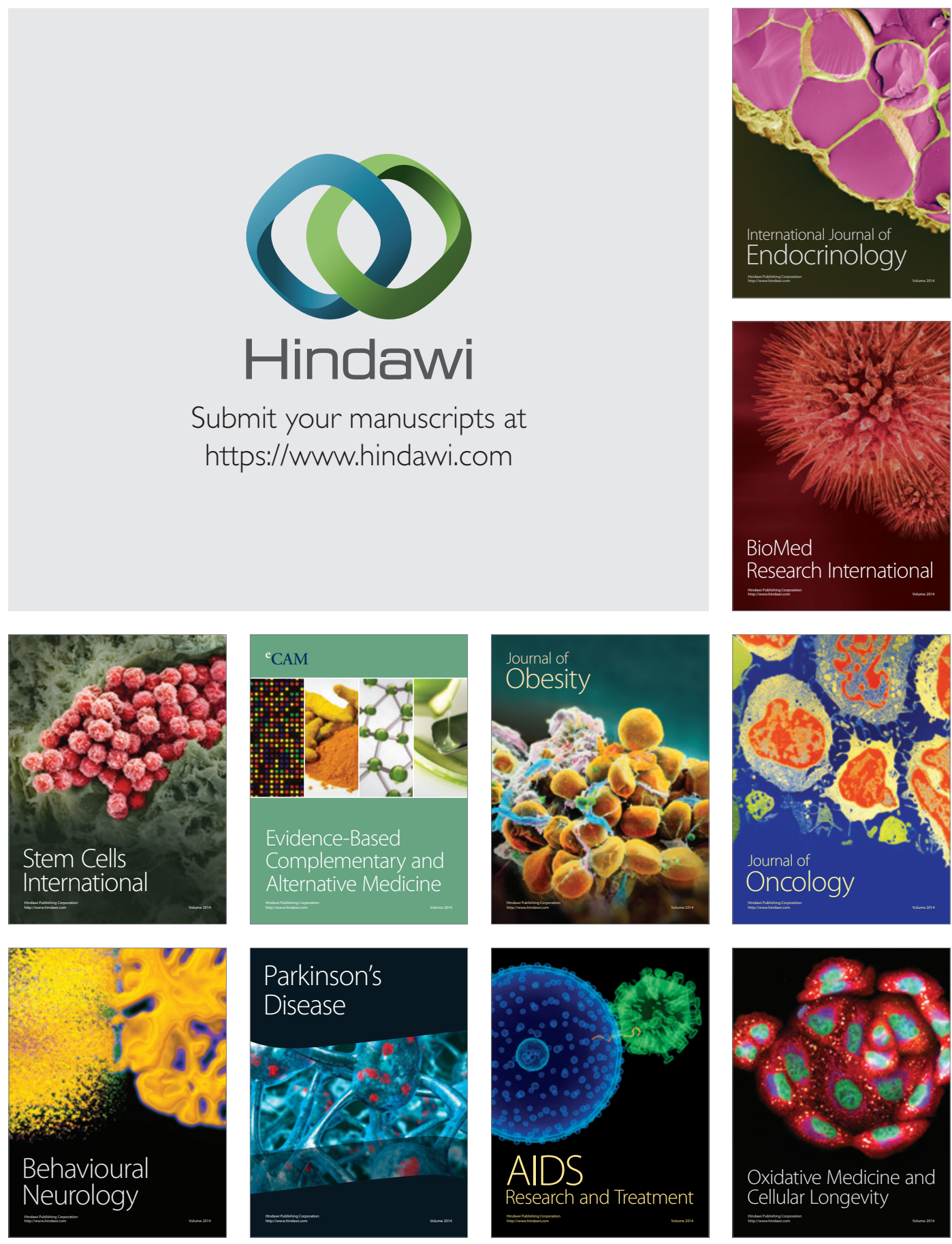